\title{
Important role of student cadres in talent development of institutions of
}

\section{higher learning}

\author{
Hailong SHAO ${ }^{1, a}$, Dongju DU², b \\ ${ }^{1}$ College of Engineering and Technology, Jilin Agricultural University, Changchun, 130118, China \\ ${ }^{2}$ College of Animal Science and Technology, Jilin Agricultural University, Changchun, 130118, \\ China \\ aemail: shaohailong1992@126.com, bemail:473352805@qq.com
}

Keywords: student cadres; institutions of higher learning; work; link

\begin{abstract}
Student cadres in institutions of higher learning have dual identities. Apart from being students, they are the backbone among students ${ }^{[1]}$, who can immediately and accurately master and reflect other students' demands and wishes, lay a solid foundation for counsellors'learning of students' ideas and targeted organization of educational activities, and help supervise the campus educational activities. As leaders of students, they undertake certain social work, and have more opportunities to get in touch with teaching staff and learn from them. All in all, they are a backbone force to achieve college goals, teaching goals of teachers and student management goals. With student cadres, various campus activities can proceed in a good order, and the expected goals can be realized. It is apt to say that student cadres act as a link between schools and students.
\end{abstract}

\section{Introduction}

Student cadres have been a main force to which institutions of higher learning pay great attention. As institutions of higher learning increase their enrolment, the number of students keeps on growing. Student management should rely not just on efforts of school leaders and teachers, but also on enhanced development of student cadres so that they can better assist schools in student management. On the one hand, student cadres help schools manage students; on the other hand or more importantly, they can better unit all students and increase class cohesion.

\section{Selection of student cadres}

Good psychological qualities

Student cadres in institutions of higher learning should have good psychological qualities so that they can be ready to cope with pressures and tasks from various aspects. Student cadres should adhere to some principles, but should also learn how to cope with student affairs based on specific conditions $^{[2]}$. All students should be treated as equals. Student cadres should not give preference to those getting on good terms with them or supporting their work and bear a grudge against those having some conflicts with them or saying no to them. To stick to principles and to unit students - these two are not contradictory. The principles student cadres adhere to fundamentally stand for immediate interests of students. By sticking to these principles, student cadres can close their relationship with other students instead of being estranged from them. 


\section{A strong sense of contribution}

To better play the role of the link between schools and students, student cadres should make efforts in the following two aspects. First, student cadres should be active, enthusiastic and creative. Second, student cadres should have more heart-to-heart talks with other students, take more initiative to publicize among other students, put down important notes and think more. By having heart-to-heart talks with other students and making friends with them, they can immediately learn practical situations and report them to school leaders. By taking more initiative to publicize among other students, they can spread correct ideas among students and motivate them. By putting down important notes, especially the important spirit of conferences, they can share important notices with other students. Besides, they should keep down ideological changes of some students and student work materials so as to expand their horizon and better guide other students. To think more means student cadres should analyze problems they encounter in their workplace, and summarize their working experiences. By doing so, they can greatly improve their thinking and working abilities.

\section{Good organizing and coordinating abilities}

Student cadres are the backbone among students, a good helper to teachers, a link between schools and students, an important part of schools' ideological and political education team, leaders of schools' favorable academic atmosphere and organizers of the prosperous campus culture ${ }^{[3]}$. The role of student cadres in publicizing, organizing, managing, serving, communicating and leading cannot be replaced by counsellors, head teachers or other teachers. Therefore, student cadres selected should have strong social adaptability and be good at organizing social activities and managing.

\section{Development of student cadres in institutions of higher learning}

Correct attitude and improve abilities of student cadres

Student cadres should set an example to other students in terms of academic study. Their academic performance can directly influence the formation of a favorable academic atmosphere. In terms of student work, student cadres should enhance their service awareness and get rid of their bureaucratic and privilege awareness. Ideological education of student cadres should go through the whole work process. Student cadres have no privileges. As to rewards for being a student cadre, the Youth League Committee and the Students' Union can provide a development platform for them so that they can have more opportunities to hone and improve their comprehensive qualities and abilities. Generally speaking, in institutions of higher learning, student cadres are from different places. Counsellors should arrange them in proper positions according to the nature of different positions and different abilities of students. Besides, counsellors should sharpen their sense of responsibility and try to fully tap potential of every student cadre.

Develop a strong sense of collective honor and creativity among student cadres

A student cadre lacking sense of honor will hardly be active, enthusiastic and creative in student work. More platforms and opportunities should be created for student cadres to experience the sense of "responsibility." Those performing well in serving and managing students and breaking new ground in terms of working methods and styles should be immediately recognized. However, as the saying goes, "humans are born to err." Teachers and schools should be tolerant to mistakes of student cadres. Before criticizing about their mistakes, counsellors should first recognize their 
efforts in student work to avoid impairing students' enthusiasm and the student-teacher relationship. Counsellors should work together with them to find out causes of their mistakes, and encourage student cadres to improve their working methods. Attention should be paid to development of student cadres' independent consciousness. Besides, student cadres should be empowered to have more rights to decide on their own.

Build and improve the assessment, reward and punishment system

Confucius says, "I reflect myself three times a day." Counsellors should encourage student cadres to periodically conduct "criticism and self-criticism." A small group of student cadres can be gathered to talk with each other sincerely and promote progress of each other. Besides, the competition mechanism should be improved, and a complete assessment, reward and punishment system should be set up among student cadres so as to fairly and justly evaluate their "morals, abilities, diligence, performance and integrity." Through the above methods, the sense of responsibility of student cadres can be greatly enhanced.

\section{Several issues related to student cadres}

Handle several relationships

The relationship between student cadres and counsellors: Counsellors bridge the communication between colleges and students. Students often have to communicate with counsellors directly. To do a good job in class management, student cadres must cope their relationship with counsellors well. On the one hand, they should immediately report classmates' ideas, learning, living and physical conditions to counsellors; on the other hand, they should convey opinions and requirements of counsellors to classmates and efficiently implement them.

The relationship between student cadres and lecturers: Lecturers can get in touch with students face to face. Student cadres play an important in linking lecturers and other students. First, student cadres need to communicate with lecturers frequently to learn lecturers' opinions of students. Then, they should spread these opinions among other students. Second, they should immediately reflect problems and suggestions of classmates to lecturers to contribute to harmony of teaching activities $^{[4]}$.

The relationship between student cadres and other students: Student cadres should first be students. They are both educators and students. As students, they should give priority to their study, finish their academic study down-to-earth, actively participate in various collective activities and get on good terms with classmates. As student cadres, they should regard safeguarding the honor of their class as a holy mission of theirs, and do a good job in linking students and school leaders, properly arranging class activities and acting as a backbone force among students.

\section{Master various roles}

Generally speaking, student cadres are outstanding in terms of morals, intelligence, PE and so on. Being highly responsible, they keep on moving ahead and are good at educating, serving and managing themselves. An excellent student cadre is a good example. Their behaviors can motivate other students. Their exemplary role is irreplaceable.

Student cadres link various school departments. They can not only spread various kinds of education information to students, but also immediately learn and collect students' opinions and suggestions and reflect them to school leaders and teachers. In this way, the communication 
between schools and students is facilitated, thus contributing to smooth progress of various school activities.

Student cadres are also ordinary students. Their top priority is learning. They should abide by regulations, participate in collective activities, assist other cadres, and become good friends with classmates. In learning, work and life, student cadres should be strict with themselves, actively cooperate to guarantee the smooth progress of various activities and play their role as an ordinary student well ${ }^{[5]}$.

\section{Enhance awareness of service and responsibility}

Student cadres should focus on the overall situations. Interests of colleges, departments and classes should be their starting point and objective. They should work hard to eliminate collective difficulties. A student cadre lacking sense of responsibility will negatively influence work of other departments, and curb the ongoing of their work. By holding various efficient service activities and giving priority to learning, student cadres can build platforms to improve students' comprehensive qualities, increase cohesion and unity among students and make their work more persuasive and guiding-effective.

\section{Conclusions}

As the educational institutional reform deepens, higher education is in a transitional period. Concerning individual differences of student cadres and new problems brought by era development, scholars should remain a clear mind, keep on updating thinking, study their characteristics and explore advanced working methods. Through enhanced training and management of student cadres in institutions of higher learning, the potential of every student cadre can be fully tapped to make them into good helpers to both teachers and counsellors.

\section{References}

[1] YAN Qinmei. How for college student cadres to play an important role among students[J]. Knowledge Library, 2016 (6).

[2] ZHAO Yanmei. Cultivation of psychological qualities of college student cadres[J]. Science and Technology, 2016 (5).

[3] JIANG Weidong. Research into an efficient long-term mechanism for academic construction of art colleges[G]. Shandong University, 2010 (9).

[4] QU Xianfeng. The Functions of Students.Cadres in Colleges and Universities[J]. Journal of Ankang Teachers College,2005(4).

[5] JI Yan. The important role of college student cadres in student management [J]. Bridge of Century,2013(13). 